\title{
The Effect of Occupational Stressors on Health and Individual Productivity: Assessments via Sobel Test
}

\author{
(Kesan Punca Stres Pekerjaan ke atas Kesihatan dan Produktiviti Individu: Penilaian melalui \\ Kajian Sobel)
}

\author{
Zafir Mohd Makhbul \\ Fakulti Ekonomi dan Pengurusan \\ Universiti Kebangsaan Malaysia
}

\author{
Sheikh Muhamad Hizam Hj. Sheikh Khairuddin \\ Faculty of Business and Management \\ Kuala Lumpur Metropolitan University College
}

\begin{abstract}
Stress is found to significantly affect academics in universities all around the world. The present research examines the issue of stress at the workplace and its effects on the health and individual productivity of the academic administrators at Malaysian research universities (MRUS). The pressure from requirements for research and development at MRUs also contributes to these problems. Based upon the survey of existing literature, stress at the workplace has a negative effect on health. The negative effects on health jeopardize individual productivity. The purpose of the present research is to determine the mediating effects of health on the relationship between occupational stressors and individual productivity. The respondents were selected based upon the proportionate stratified random sampling method. 300 questionnaires were collected from the academic administrators of 5 MRUs. A 100 per cent response rate was obtained. The research instrument used for the stress and health component was adopted from the ASSET (A Shortened Stress Evaluation Tool). Common occupational stressors in the workplace include work relationships; work-life balance; overload; job security; control; resources and communication; and pay and benefits. Meanwhile, health is represented by physical health and psychological well-being. Finally, the productivity of the academic administrators is based upon their common duties and responsibilities, which include teaching, supervision, publication, training, student service, administrative duties and social responsibility productivity. The aforementioned aspects of productivity are considered in the annual performance appraisal reviews of academic administrators performed by the MRUs. The stressors are analyzed dimensionally, while health and individual productivity are measured aggregately. The statistical techniques used in this study include multiple regression analysis and Sobel tests. The results show that certain occupational stressors are significantly, but negatively, related to health, such as work relationships, work-life balance, job security, control and aspects of the job (i.e., physical working conditions, type of tasks and the amount of satisfaction derived from the job). Additionally, certain occupational stressors are found to be significantly, but negatively, related to individual productivity, including work relationships; work-life balance; job security; control; resources and communication; and pay and benefits. Finally, the results indicate that health partially mediates the relationship between work relationships, work-life balance, job security, control and individual productivity.
\end{abstract}

Keywords: Stress, health; productivity; research university; sobel test.

ABSTRAK

Stres telah memberi kesan signifikan kepada dunia akademik di universiti seluruh dunia. Kajian ini telah mengkaji isu stres di tempat kerja dan kesannya terhadap kesihatan dan produktiviti individu terhadap pentadbir akademik di universiti penyelidikan di Malaysia. Tekanan daripada keperluan penyelidikan dan pembangunan di universiti penyelidikan juga menyumbang kepada permasalahan yang sedang dikaji. Berdasarkan kepada tinjauan literatur, stres di tempat kerja memberi kesan negatif kepada kesihatan. Kesan negatifitu seterusnya menjejaskan produktiviti individu. Tujuan utama kajian ini adalah untuk menentukan fungsi kesihatan sebagai faktor pengantara kepada perhubungan punca stres pekerjaan dengan produktiviti individu. Responden yang terlibat dipilih secara rawak berstrata berkadaran. Kesemua 300 borang soalselidikyang diedar telah berjaya dikumpul daripada pentadbir akademik di 5 buah universiti penyelidikan di Malaysia, menjadikan kadar maklumbalas 100 peratus. Instrumen kajian bagi komponen stres dan kesihatan diadaptasi daripada ASSET (A Shortened Stress Evaluation Tool). Punca stres yang biasa di tempat kerja terdiri daripada perhubungan kerja; keseimbangan kehidupan peribadi - kerjaya; beban kerja berlebihan; jaminan 
kerja; kawalan; sumber dan komunikasi; serta gaji dan faedah. Aspek kesihatan pula diwakili oleh kesihatan fizikal dan kesejahteraan psikologi. Pengukuran produktiviti individu pentadbir akademik dibuat berdasarkan kepada tanggungjawab dan tugasan hakiki mereka iaitu pengajaran, penyeliaan, penerbitan, latihan, perkhidmatan kepada pelajar, tugas pentadbiran dan tanggungjawab sosial. Kesemua aspek produktiviti tersebut diambilkira dalam penilaian prestasi pentadbir akademik di universiti penyelidikan. Punca stres dianalisis secara berdimensi, manakala kesihatan dan produktiviti secara agregat menggunakan kaedah analisis regresi berbilang dan ujian Sobel. Keputusan ujian statistik menunjukkan bahawa sesetengah punca stres berhubung secara signifikan dan negatif dengan kesihatan seperti perhubungan kerja, keseimbangan kehidupan peribadi - kerjaya, jaminan kerja, kawalan dan aspek kerja (iaitu keadaan fizikal kerja, jenis tugas dan amaun kepuasan kerja yang diperoleh daripada sesuatu kerja). Seterusnya, sesetengah punca stres juga berhubung secara signifikan dan negatif dengan produktiviti. Ia meliputi perhubungan kerja, keseimbangan kehidupan peribadi - kerjaya, jaminan kerja, kawalan, sumber dan komunikasi serta gaji dan faedah. Kesimpulannya, penemuan ini membuktikan bahawa faktor kesihatan memberi kesan secara separa sebagai pengantara kepada hubungan antara perhubungan kerja, keseimbangan kehidupan peribadi-kerjaya, jaminan kerja, kawalan dan produktiviti.

Kata kunci: Stres; kesihatan; produktiviti; universiti penyelidikan; ujian sobel.

\section{INTRODUCTION}

The new key performance indicators (KPIs) for Malaysian research universities (MRUs) are creating extra pressure for academics, especially those holding administrative posts. Academics holding administrative posts are likely to face greater stress in lieu of the new KPIs and surplus targets. Associate professors and professors who hold the position of academic administrator perform other functions, such as chairing or attending meetings, that are not restricted to producing academic papers alone. Such individuals may not have time to excel in both areas. Furthermore, academics holding administrative posts are under extra pressure because the aforementioned KPIs are also linked to their promotion and tenure. Additionally, certain individual productivity areas of the academics or academic administrators have received little attention in existing literature, such as faculty advising (student service) and training (Rosser \& Tabata 2010); supervision (Crosta \& Packman 2005); and service (include administrative duties and social responsibility) (Hassan, Tymms \& Ismail 2008). The present study provide a new, comprehensive and valid individual productivity measurement of such components, including teaching productivity, supervision productivity, publication productivity, training productivity, student service productivity, administrative duty productivity and social responsible productivity. Finally, gaps are found in existing research relating to stress and productivity studies. Certain stressors have not yet been studies in the Malaysian workplace, including work relationships; work-life balance; overload; job security; control; resources and communication; aspects of the job (i.e., physical working conditions, type of tasks, and amount of job satisfaction); and pay and benefits. Research concerning the mediating effects of health on the relationships between these variables is scarce and no extant research examines Malaysian workplaces specifically. Novel outcomes such as individual productivity are also rarely studied upon generally
(Kelloway, Teed \& Kelley 2008). The study of stress and productivity among academic administrators within MRUs has also been neglected.

Most of the time, stress is said to have a direct effect on individual productivity (e.g. Tarafdar, Tu, RaguNathan \& Ragu-Nathan 2007). Jacobs, Tytherleigh, Webb \& Cooper (2007) examine stress at academic institutions using a sample of 13 United Kingdom universities on non-academic and academic and research staff and find that stress affects productivity. A negative linear relationship is found between occupational stressors and numerous performance measures associated with self-rated productivity, research and teaching assessment. Meanwhile, Donald, Taylor, Johnson, Cooper, Cartwright and Robertson (2005) find that occupational stressors, such as resources and communications; psychological well-being; and organizational commitment, predict self-rated productivity. The study is claimed to be generalizable to multiple industries study with a large sample size (i.e., $\mathrm{N}=16,001)$. Stress can also directly contribute to poor health (Phillips, Sen \& McNamee 2008; Viljoen \& Rothmann 2009).

However, stress can also have an indirect effect on individual productivity. Gaps exist in studies examining the indirect effects of stress in general. Meanwhile, Donald et al. (2005) also suggest that the failure to determine the direct effects of stress could be due to the existence of indirect effects in this relationship. Stress also carries cost implications for firms, which can be incurred directly through health care cost (Manning, Jackson \& Fusilier 1996); or indirectly through absenteeism and presenteeism (Mostert, Rothmann, Mostert \& Nell 2008). Greenberg, Stiglin, Finkelstein and Berndt (1993) report that the financial costs of work-health related diseases, such as depression at the workplace, among corporations in the United States of America amounted to approximately USD12.1 billion in productivity losses during 1990 alone

The objectives of the present study are: (1) to develop a scale to measure new individual productivity 
components (i.e. teaching, supervision, publication, training, student service, administrative duty, and social responsibility productivity); (2) to determine the direct effects of occupational stressors on health and new individual productivity measures; and (3) to determine the mediating effects of health on the relationship between occupational stressors and individual productivity among academic administrators at MRUs. The following research questions are examined: (1) Is the new individual productivity measure valid and reliable?; (2) Are the dimensions of occupational stressors related to health and individual productivity?; and (3) Does health mediate the relationship between occupational stressors and individual productivity? The present study contributes to the knowledge of stress and productivity, as well as health as a mediator in the relationship between stress and productivity in the context of academic administrators at MRUs. The findings will help to understand the linkages that exist between the variables (i.e., occupational stressors, health and individual productivity).

The remainder of the paper is structured as follows. The next section presents the literature review, hypothesis development, and conceptual framework concerning occupational stressors, health, and individual productivity. The third section presents the methodology employed for the present study. The fourth section presents the results and analysis of the direct and mediating effects of health on stress and productivity. Finally, the findings and conclusions from the study are presented.

\section{LITERATURE REVIEW}

\section{OCCUPATIONAL STRESSORS}

Occupational stressors are defined as the sources of stress commonly found at the workplace. The notion that job conditions are the cause of stress at the workplace is generally accepted (Zafir 2012a; Spector, Dwyer \& Jex 1988). According to the Beehr and Newman's (1978) general model of stress, the environmental facet consists of elements of an employee's work environment that are likely to be the cause of work stress. In this study, the ASSET (A Shortened Stress Evaluation Tool) model of stress (Cartwright \& Cooper 2002) is utilized. The construct is well-known and the latest construct of stress, currently used by many organizations as an organizational stress screening tool (Viljoen \& Rothmann 2009). The construct validity for the measure of stress using the ASSET scale has been well established in existing literature (Johnson \& Cooper 2003). According to Faragher, Cooper and Cartwright (2004), the ASSET is a shortened stress evaluation tool that consists of a quick and easy test that is able to generate a high response rate. According to the model, eight stressors are commonly found in the workplace: work relationships; work-life balance; overload; job security; control; resources and communication; aspects of the job; and pay and benefits.
Work Relationships - Work relationships are operationally defined as the work relationships between colleagues and/or superiors. Most jobs require working with people. Thus, poor or unsupportive colleagues, subordinates and bosses are a potential source of stress (Cartwright \& Cooper 2002).

Work-Life Balance - In the present study, work-life balance is defined as balancing the differing demands of home and work. The demands of work have the potential to spillover and interfere with one's personal life (Cartwright \& Cooper 2002).

Overload - In the present study, overload is defined as unmanageable workloads and time pressures. Unmanageable workloads and time pressure can be a source of stress (Cartwright \& Cooper 2002). The Trade Union Council's (2000) survey, for example, identifies high workload as the main cause of stress for employees.

Job security - Expectations concerning a lifelong career is the definition of job security in the study. Contemporary employees do not expect life time employment, but the fear of losing a job still remains a potential source of stress (Cartwright \& Cooper 2002).

Control - The definition of control in the study is the perception of control over the environment, such as in how work was organized and performed. The experience of stress is strongly linked to perceptions of control.

Resources and Communication - Resources and communication refer to whether employees are provided with appropriate training, equipment and resources; whether employees are adequately informed; and whether employees are valued. To perform their job effectively, employees need to have appropriate training, equipment and resources. Employees also need to be adequately informed and are valued (Cartwright \& Cooper 2002).

Aspects of the Job-Aspects of the job in the present study is defined as factors that include physical working conditions; type of tasks; and the amount of satisfaction derived from the job. The potential sources of stress can be related to the fundamental nature of the job itself.

Pay and Benefits - Pay and benefits are defined as the financial rewards that work brings. The financial rewards that work brings are obviously important since they determine which type of lifestyle that an individual can lead. In addition, they often influence 
the individual's feelings of self-worth and value to the organization (Cartwright \& Cooper 2002).

\section{HEALTH}

Most of the existing theories and variables of stress are identified in the meta model of Beehr and Newman (1978) (Beehr 1995, 2002). This general theory of stress states that the human consequences facet consists of physical and mental health. In this study, health is defined as stress induced physical health and psychological well-being of the individuals. Stress is a non-specific bodily response made to any demand (Selye 1973) or commonly known as the General Adaptation Syndrome (GAS). According to Selye's (1976) general theory of stress, the effects of stress are cumulated over time and are related to morbidity and pathology if not abated. In other words, the outcomes of stress are aggravated by the passage of time and the number and severity of stressors experienced, the eventual results will inevitably be serious disease and/or death of the organism.

Occupational stress has an impact on worker's mental and physical well-being (Kahn \& Byosierre 1992). According to Winefield, Gillespie, Stough, Dua and Hapuarachchi (2003), significant evidence exists that chronic and high levels of occupational stress, if left unchecked, are related to mental and physical wellbeing, job dissatisfaction, absenteeism, stress-related injuries, turnover and intention to quit. In extant studies, all administrators and coordinators demonstrate high levels of poor physical health due to the effects of stress (Zafir 2012b; Michailidis \& Asimenos 2002). Among head teachers, stress also affected their physical health (Phillips et al. 2008). Psychological health refers to clinical symptoms indicative of stress induced mental health issues (e.g. constant tiredness, and irritability) (Viljoen \& Rothmann 2009). Psychological distress can cause more serious reversible health problems (e.g., psychosomatic illnesses, arterial hypertension, severe depression, alcoholism).

\section{INDIVIDUAL PRODUCTIVITY}

The individual productivity of academics or academic administrators in most studies is defined as teaching, research and service (e.g. Hassan et al. 2008; Mamiseishvili \& Rosser 2010; Provost 2005; Rosser \& Tabata 2010). The present study defines individual productivity as teaching, supervision, publication, training, student service, administrative duties and social responsibility outputs.

Teaching - Teaching is labeled as a "local phenomenon" (Blackburn \& Lawrence 1995). However, the teaching reputation or excellence of a university is generally only perceived within the campus without any national recognition. Meanwhile, Malaysian public academics perceive teaching as a more productive activity compared to research and administration (Hassan et al. 2008). Therefore, teaching productivity is measured in terms of the number of courses taught.

Supervision - The supervision of student research projects is a specialist form of teaching, but others view the activity as a part of research (Ketteridge $\&$ Shiach 2009). According to James and Baldwin (2006), supervision involves the fundamentals of good teaching, including concern for students; interest in their progress; and the provision of thoughtful and timely feedback. Therefore, the number of theses supervised is measured.

Publication - The most popular or commonly used measure of publications is the number of published articles in journals (Creswell 1985; Mamiseishvili \& Rosser 2010). The most recent measurement is the qualitative nature of publication productivity (e.g., peer-reviewed journals) (Print \& Hattie 1997). According to Middaugh (2001), even though the number of journals, books and conference papers are quantifiable, they are considered as the qualitative measures of publication productivity. The number of published works in peer-reviewed journals, books and conference papers reveal information concerning the quality of the individual's research activities. Three measures of publication productivity utilized in the present study are the number of articles published in refereed journals; the number of books authored/co-authored/edited/translated; and the number of papers presented or published in proceedings/professional conferences/seminars.

Training - Faculties can also be involved in conducting training (e.g. in the use of analytical instruments) (University of Nevada 2007). Training productivity is therefore, measured by the number of training activities conducted.

Student Service - This area has received little attention from academics (Rosser \& Tabata 2010). According to Kennedy (1997), the mission of the university and the duty of the faculty are to work close with the students. Furthermore, research demonstrates that working with the students improve satisfaction among members of the faculty (Hagedorn 1996). In the present study, student service productivity is defined as activities involving the advising and mentoring of students (e.g., as an academic advisor). Therefore, the number of students mentored/advised formally is measured.

Administrative Duties - Other than teaching and research work, administrative duties are considered as a service (Blackburn \& Lawrence 1995). However, 
the importance of administrative duties cannot be denied. Administrative duties generally indicate commitment to the university. In the present study, administrative duties are defined as the activities that involve the work of internal committees (e.g. hiring committee; and senate committee, whether chairing or serving as a member). According to Miller (2003), university committee positions will include members from all levels, including the program level, the department/school level, the college level and the university level. Therefore, the number of internal committees participated is measured.

Social Responsibility - The activities involving social responsibility on the part of academics include participating in external committees or organizations outside the university including activities services provided to the government; professional associations; public and community organizations; other universities; external examinations of theses; consultancy; and the media, such as appearances on television and radio. According to Middaugh (2008), public services include faculty extension and outreach activities, such as civic service; community workshops; and invited talks to community groups, seminars, lectures or demonstrations. Therefore, in the present study, the number of external services activities participated is measured.

Academics or academics with administrative duties (i.e., academic administrators) at MRUs are evaluated using the seven criteria above in their annual performance appraisal. From the theoretical perspective, the occupational stressors from the work environment cause human consequences that result in organizational consequences, which is called the stress process. According to Bechr and Newman's (1978) general theory of stress, organizational consequences consist of key aspects of organizational effectiveness that may be affected by job stress. In the present study, the focus of organizational consequences is on individual productivity whereby only output measures are quantified. This can be seen in other studies (e.g., Blackburn \& Lawrence 1995; Massy \& Wilgers 1995; Hassan et al. 2008).

\section{DIRECT EFFECTS OF OCCUPATIONAL STRESSORS ON HEALTH}

Bechr and Newman's general theory of stress (1978) represents all of the elements found in stress studies. In the present study, occupational stressors represent environmental facets of stress, while health is perceived as the human consequences facet. Furthermore, according to interactional theory (Beehr \& Franz 1987), stress is represented by the stimulus of, and response to, stress in order to provide a more complete view of the dynamics of stress. The relationship or the theoretical link between the environmental facet and the human consequences facet is demonstrated utilizing the stressors-strains approach, which is illustrated by the occupational stress model of Beehr (1995). Additionally, the ASSET model of stress (Cartwright \& Cooper 2002) shows the theoretical link between the sources of stress, such as poor work relationships, and the effects of stress, such as poor health. Poor work relationships can negatively impact health. Using ASSET, studies conducted by Jackson and Rothmann (2006); Tytherleigh, Webb, Cooper and Ricketts (2005); and Viljoen and Rothmann (2009) show that poor work relationships are negatively related to health. Job security predicts physical health and psychological well-being, while overload and job aspects predict psychological well-being (Viljoen \& Rothmann 2009; Zafir, Syed, Shaza \& Norliza 2011). In a study by Mostert et al. (2008), job overload predicts psychological ill health in support staff. Meanwhile, in another study, Bridger, Kilminster and Slaven (2007) find that role conflict predicts strain using a similar multiple regression analysis technique. According to Phillips et al. (2008), head teachers report higher levels of workrelated stress and their psychological health is poor compared to other professionals. In studies examining the staff of municipal administrations, work stress predicts significant emotional exhaustion and depersonalization (Zafir \& Fazilah 2007; Zafir, Zizah \& Nor Liza 2013). Hence, $\mathrm{H} 1$ of the present study is as follows:

H1a: Poor work relationships are negatively related to health

H1b: Work-life imbalance is negatively related to health

H1c: Overload is negatively related to health

H1d: Job insecurity is negatively related to health

H1e: Poor job control is negatively related to health

H1f: Poor resources and communication are negatively related to health

H1g: Poor aspects of the job are negatively related to health

H1h: Poor pay and benefits are negatively related to health

\section{DIRECT EFFECTS OF HEALTH ON INDIVIDUAL PRODUCTIVITY}

As an extension of the stressors-strain theory discussed previously, elements of environmental, human consequences are linked with organizational consequences. The Beehr's occupational stress model (1995) is able to explain this phenomenon. According to the model, occupational stressors affect human consequences and, in turn, lead to the organizational consequences of stress. Aronsson, Gustafsson and Dallner (2000); Brouwer, Koopmanscap and Rutten (1999); Heuval, Geuskens, Hooftman, Koppes and Bossche (2010); and Schultz and Eddington (2007) find that, poor health leads to a loss of productivity through sickness absence (days off work) and sickness presenteeism (reduced performance at work). These health-related 
productivity costs are four times greater than medical and pharmacy costs (Loeppke, Taitel, Richling, Parry, Kessler, Hymel \& Konicki 2007). Finally, Boles, Pelletier and Lynch (2004) discover that the greater the health risks, the higher the productivity losses. Administrators and coordinators rated above-average for poor physical and mental health due to stress in the study of a large Cyprus university (Michailidis \& Asimenos 2002). The health or human consequences have organizational consequences (Beehr \& Newman 1978; Cartwright \& Cooper 2002). Scholarly productivity also contributes to increased stress levels for Australian deans (Gmelch, Wolverton, Wolverton \& Sarros 1999). Using ASSET, high teaching scores of Guardian Teaching Score (GTS) is associated with good physical health (Jacobs et al. 2007). In another study, the psychological well-being of the academics from 17 Australian universities is found to be highly correlated with objective measures of the university well-being, such as investment income; student-staff ratios; and recent cuts in staffing levels and in government operating grants (Winefield et al. 2003). As a conclusion, poor health as a result of stress results in poor individual productivity. Therefore, H2 is as follows:

H2: Poor health due to stress is positively related to poor individual productivity.

\section{DIRECT EFFECTS OF OCCUPATIONAL STRESSORS ON INDIVIDUAL PRODUCTIVITY}

The best known theory concerning the relationship between stress and productivity is the Yerkes-Dodson law regarding motivation and drives (Young 1936). Job arousal or stressors creates performance. Three inverted U-shaped curves are utilized to explain the concept and demonstrated that performance increases with increasing arousal up to a point. Beyond that point, performance will decrease. However, recent developments in stress-productivity research points to a negative linear relationship between stress and productivity. Jamal (1984) examine the relationship between occupational stressors and employee performance in nurses; and find that the relationship is negatively correlated. Abramis (1994) also finds a negative linear relationship between role conflict, role ambiguity, job insecurity and job performance as measured by the respondents and the co-workers. Empirically, the stressors from the ASSET model show a negative relationship with productivity measures. Therefore, $\mathrm{H} 3$ is as follows:

$\mathrm{H} 3 \mathrm{a}$ : Poor work relationships are negatively related to individual productivity

$\mathrm{H} 3 \mathrm{~b}$ : Work-life imbalance is negatively related to individual productivity

H3c: Overload is negatively related to individual productivity

H3d: Job insecurity is negatively related to individual productivity
H3e: Poor job control is negatively related to individual productivity

H3f: Poor resources and communication are negatively related to individual productivity

$\mathrm{H} 3 \mathrm{~g}$ : Poor aspects of the job are negatively related to individual productivity

H3h: Poor pay and benefits are negatively related to individual productivity

\section{THE ROLE OF HEALTH}

From Beehr and Newman's general theory of stress (1978), some of the common elements found in most stress studies are environmental, human consequences and organizational consequences facets. The linking of these facets is based upon the Beehr's occupational stress model (1995). In this model, occupational stressors in the work environment facet produce strains in the human consequences facet and, in turn, affect job performance in the organizational consequences facet. Studies conducted by Jackson and Rothmann (2006), Tytherleigh et al. (2005), and Viljoen and Rothmann (2009) show that poor work relationships are negatively related to health. Meanwhile, Aronsson et al. (2000), Brouwer et al. (1999), Heuval et al. (2010), and Schultz and Eddington (2007) find that poor health is positively related to poor productivity. Using ASSET, Jacobs et al. (2007) also show that poor health is positively related to poor individual productivity. Darr and Johns (2008) demonstrate that health is a mediator in stress studies and find support in somatic and psychological illness mediating the stressor-absence relationship. Other studies, such as Lang, Thomas, Bliese and Adler (2007), also support the mediating effects of physical and psychological strain on the relationship between job demands and job performance. Finally, Webster et al. (2009) find that the physical symptoms of strains partially support the challenge and hindrance stressors and behavioral outcomes, such as organizational citizenship behavior and job performance. Therefore, $\mathrm{H} 4$ is as follows:

H4a: Poor health mediates the relationship between poor work relationships and poor individual productivity

H4b. Poor health mediates the relationship between work-life imbalance and poor individual productivity

H4c. Poor health mediates the relationship between overload and poor individual productivity

$\mathrm{H} 4 \mathrm{~d}$. Poor health mediates the relationship between job insecurity and poor individual productivity

H4e. Poor health mediates the relationship between poor job control and poor individual productivity

H4f. Poor health mediates the relationship between poor resources and communication; and poor individual productivity 
H4g. Poor health will mediate the relationship between poor aspects of the job and poor individual productivity

H4h. Poor health will mediate the relationship between poor pay and benefits and poor individual productivity

\section{CONCEPTUAL FRAMEWORK}

A conceptual framework of individual productivity is derived for the present study (Figure 1). The model is an extension of the previous models examining stressorsstrain relationship. In this study, occupational stressors are measured in terms of work relationships; work-life balance; overload; job security; control; resources and communications; aspects of the job; and pay and benefits. Health is measured by physical health and psychological well-being. Finally, individual productivity is measured through objective measures of individual productivity, which include teaching, supervision, publication, training, student service, administrative duties and social responsibility productivity. The levels of analysis for occupational stressors are conducted at the dimensional levels. Meanwhile, the levels of analysis for commitment, health and individual productivity are conducted at aggregate levels. In this framework, direct relationships between occupational stressors, commitment, health and individual productivity; and indirect relationships between occupational stressors and individual productivity through commitment and health are hypothesized. The causal relationships are analyzed using multiple regression analysis and Sobel test methods.

\section{METHODOLOGY}

The total population of the academic administrators in MRUs consists of 903 people. The 5 research universities are Universiti Kebangsaan Malaysia, Universiti Malaya, Universiti Putra Malaysia, Universiti Sains Malaysia and Universiti Teknologi Malaysia (UKM website 2010; UM website 2010; UPM website 2010; USM website 2010; UTM

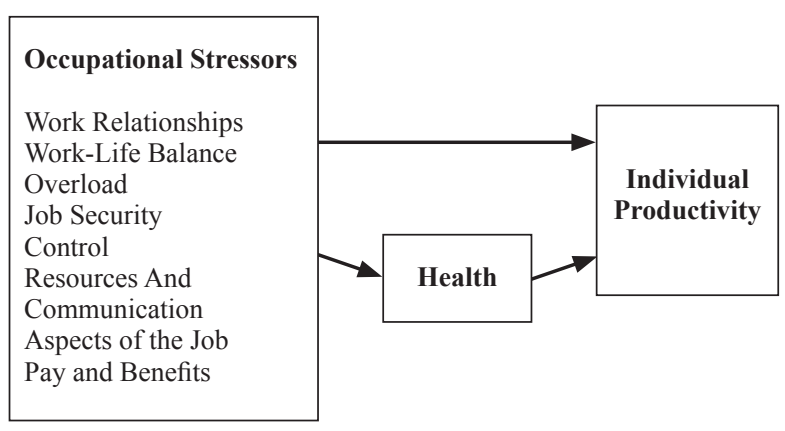

FIGURE 1. Conceptual framework of occupational stressors, health and individual productivity website 2010). To determine the sample size required from the number of population, the Krejcie and Morgan table (Krejcie \& Morgan 1970) is utilized. From this table, the minimum required sample size for this population size is 274 . A lump sum figure of 300 respondents was selected. The proportionate stratified random sampling technique is used to determine the sample size for each MRU and is based upon the total academic administrators of an MRU divided by the total population of the academic administrators in all MRUs and multiplied by 300 . The sample size required for each research university is depicted in Table 1, below.

TABLE 1. Total sample size required

\begin{tabular}{lc}
\hline Research university & $\begin{array}{c}\text { Total sample size } \\
\text { required }\end{array}$ \\
\hline Universiti Kebangsaan Malaysia & $(218 / 903) \times(300)=72$ \\
Universiti Malaya & $(135 / 903) \times(300)=45$ \\
Universiti Putra Malaysia & $(139 / 903) \times(300)=46$ \\
Universiti Sains Malaysia & $(268 / 903) \times(300)=89$ \\
Universiti Teknologi Malaysia & $(143 / 903) \times(300)=48$ \\
\hline Total & 300 \\
\hline
\end{tabular}

A pilot test was conducted in the light of the fact that the survey will be conducted in a different country whereby different culture may play a part in the results. A pilot survey of 22 academic administrators from an MRU was collected. Positive feedback was received from the respondents regarding the survey questions posed to them, particularly in regards to the clear and understandable wording of items. All of the items in the questionnaire were maintained and none were dropped. The questionnaires have a good content and face validity. Meanwhile, to test for the reliability of the scale used, a reliability analysis was conducted using SPSS version 17.0. All variables are found to have Cronbach alphas greater than 0.70 (Table 2). To interpret these values, the George and Mallery's (2001) guide to the interpretation of Cronbach's alpha is utilized. Work relationships and individual productivity scale reliabilities are found to be good. Meanwhile, work-life balance, overload, job security, control, resources and communication, aspects of the job and health reliabilities are acceptable. Therefore, the scale of items used in the present study is reliable. The summary of the number of items and reliabilities of variables are depicted in Table 2.

To fulfill multivariate assumptions, further tests are also conducted, including tests for normality, linearity, and homoscedasticity of the distributions. The results demonstrate that the distributions for each of the variables are normal, linear, and homoscedastic. To analyze for multicollinearity, collinearity statistics are conducted. The results also demonstrate that the tolerance values for all independent variables are above 
TABLE 2. Variable, number of items and reliability

\begin{tabular}{lccc}
\hline Variable & \multirow{2}{*}{$\begin{array}{c}\text { No. of } \\
\text { items }\end{array}$} & \multicolumn{2}{c}{ Reliability } \\
\cline { 3 - 4 } & & $\begin{array}{c}\alpha \text { (pilot } \\
\text { test) }\end{array}$ & $\begin{array}{c}\alpha \text { (field } \\
\text { test) }\end{array}$ \\
\hline Work relationships & 8 & 0.89 & 0.88 \\
Work-life balance & 4 & 0.72 & 0.75 \\
Overload & 4 & 0.79 & 0.84 \\
Job security & 4 & 0.71 & 0.72 \\
Control & 4 & 0.73 & 0.77 \\
Resources and communication & 4 & 0.74 & 0.81 \\
Aspects of the job & 8 & 0.71 & 0.78 \\
Pay and benefits & 1 & - & - \\
Health & 17 & 0.74 & 0.76 \\
Individual productivity & 9 & 0.83 & 0.84 \\
\hline Total & 63 & & \\
\hline
\end{tabular}

0.2 (Table 3), which indicates that they are free from multicollinearity problems. The variance inflation factor (VIF) for the variables is also less than 10, indicating that multicollinearity problems are minimal. The results are shown in Table 3.

All occupational stressors items are measured on a 6-point scale ranging from 1 (strongly disagree) to 6 (strongly agree), whereas health is measured using a 4-point scale ranging from 1 (Never) to 4 (Often). The health items are reversely-coded because they are negatively-worded items. This means that, the higher the health scores are, the higher the health levels are. Finally, all of the individual productivity items are measured using a 5 -point scale ranging from 1 (None) to 5 (4 or more). These scales are standardized to compute the scores aggregately. An exploratory factor analysis is conducted to test the construct validity of the variables. For bivariate analysis or to measure the association between two variables, correlation analysis is conducted between the 10 variables. To determine the cause and effect relationship or the direct effects between the stressors, health, and individual productivity, multiple regression analysis techniques are employed. The final

TABLE 3. Collinearity statistics (field data)

\begin{tabular}{lcc}
\hline \multirow{2}{*}{ Model } & \multicolumn{2}{c}{ Collinearity statistics } \\
\cline { 2 - 3 } & Tolerance & VIF \\
\hline Work relationships & 0.420 & 2.379 \\
Work-life balance & 0.605 & 1.653 \\
Overload & 0.333 & 3.002 \\
Job security & 0.529 & 1.889 \\
Control & 0.730 & 1.370 \\
Resources and communication & 0.431 & 2.319 \\
Aspects of the Job & 0.299 & 3.344 \\
Pay and benefits & 0.484 & 2.065 \\
Health & 0.681 & 1.468 \\
\hline
\end{tabular}

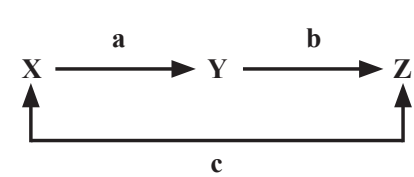

FIGURE 2. Mediational paths diagram

analysis of the present study concerned the indirect effect or mediation analysis. Health, as a mediator, is tested to determine the indirect relationships of the occupational stressors on individual productivity. Mediation is a hypothesized causal chain in which one variable affects a second variable that, in turn, affects a third variable (Newsom 2010). As depicted in Figure 2, $\mathrm{Y}$ is the mediator variable and mediates the relationship between the $\mathrm{X}$ predictor and the $\mathrm{Z}$ outcome. Path $a$ and Path $b$ are referred to as the indirect effects, while Path $c$ is the direct effect.

The present study utilizes the meditational procedures of Baron and Kenny (1986) and Judd and Kenny (1981). The size and the significance of the indirect relationships are also tested. According to Baron and Kenny (1986), the amount of indirect effect is the product of two effects, which involves the multiplication of the coefficients of Path $a$ and Path $b$. A Sobel test (Sobel 1982) is conducted to determine the significance of the indirect relationships of the study in a single test. The unstandardized coefficients of Path $a$ and Path $b$, as well as their standard errors, are formed as inputs and calculated using the interactive calculator (Preacher \& Leonardelli 2010). A regression analysis is performed. The independent variable (IV) predicts the mediator and yields the unstandardized coefficient and standard error $\left(\mathrm{S}_{\mathrm{a}}\right)$ of Path $a$. Meanwhile, a second regression analysis involving IV and together with the mediator will predict the dependent variable (DV) that provides an unstandardized coefficient and standard error $\left(\mathrm{S}_{\mathrm{b}}\right)$ of ' $\mathrm{b}$ ' and . To conduct the Sobel test, data is input into the cells below (Table 4), can be reset and calculated by using the interactive calculator. A $p$-value of less than 0.05 indicates that the mediation is significant. Otherwise, the mediation is not significant.

\section{RESULTS AND ANALYSIS}

TABLE 4. Sobel test using an interactive calculator

\begin{tabular}{lcccc}
\hline & Input: & Test statistic: & Std. error: & $p$-value: \\
\hline $\mathrm{a}$ & & & \\
$\mathrm{b}$ & & & \\
$\mathrm{S}_{\mathrm{a}}$ & & & \\
$\mathrm{S}_{\mathrm{b}}$ & & & \\
\hline & Reset all & & Calculate \\
\hline
\end{tabular}


A 100 per cent response rate was achieved from 300 questionnaires distributed to the academic administrators of five MRUs: Universiti Kebangsaan Malaysia, Universiti Malaya, Universiti Putra Malaysia, Universiti Sains Malaysia and Universiti Teknologi Malaysia. The detailed stratified sample characteristics of each university are shown in Table 5. Finally, the total sample of the MRUs (i.e. 300 samples) is analyzed. Overall, the total sample characteristics for the MRUs show typicality in several demographic levels: the age between 41 to 50 years old; income level between RM5000 to RM10 000; sex of male; educational level at the $\mathrm{PhD}$ or equivalent level; and employment status of a full-time employee.

Each MRU is analyzed regarding the study variables to search for the significance of differences. The results in Table 6 show that none of the variables are significant between the groups ( $p$ value $>0.05$ ). The results indicate that no need exists to control for organizations in the regression analysis.

The results from the exploratory factor analysis study are discussed here. According to Cavana, Dlahaye and Sekaran (2001) and Kerlinger and Lee (2000), significant loadings are 0.30 and above. From the results, all factor loadings for each variable contribute significantly at 0.30 and above. The reliabilities of the associated scales used are also found to be good and acceptable (Cronbach's alpha more than 0.80 and 0.70 ). This indicates that the construct validity and reliability of work relationships; work-life balance; overload; job security; control; resources and communications; aspects of the job; health; and individual productivity each are significant. Correlation analysis results show that all occupational stressors are significant and negatively related to health and individual productivity at the $\mathrm{p}<0.01$ levels. Meanwhile, health and productivity are also significant, but positively related, at the same level.

\section{MULTIPLE REGRESSION ANALYSIS}

The multiple regression analysis method is utilized to determine the direct effects of occupational stressors on health. The $\mathrm{R}^{2}$ for this model is 0.441 , which indicates that $44.1 \%$ of the variances in predicting health are explained by this model. Work relationships, work-life balance, job security, control and aspects of the job are all found to be significant and negatively related to health. The largest contribution made by the individual stressor is work relationships $(\beta=-0.449 ; \mathrm{p}=0.000)$, which was followed by job security $(\beta=-0.235 ; \mathrm{p}=0.001)$; aspects of the job $(\beta=-0.228 ; \mathrm{p}=0.014)$; work-life balance

TABLE 5. Stratified sample characteristics for each Malaysian research universities

\begin{tabular}{|c|c|c|c|c|c|c|c|c|c|c|}
\hline \multirow{2}{*}{$\begin{array}{l}\text { UNIVERSITY / } \\
\text { DEMOGRAPHIC }\end{array}$} & \multicolumn{2}{|c|}{ UKM } & \multicolumn{2}{|c|}{ UM } & \multicolumn{2}{|c|}{ UPM } & \multicolumn{2}{|c|}{ USM } & \multicolumn{2}{|c|}{ UTM } \\
\hline & Freq. & $\%$ & Freq. & $\%$ & Freq. & $\%$ & Freq. & $\%$ & Freq. & $\%$ \\
\hline \multicolumn{11}{|l|}{ Age (years) } \\
\hline $31-40$ & 14 & 19.4 & 9 & 20.0 & 9 & 19.5 & 21 & 23.6 & 11 & 22.9 \\
\hline $41-50$ & 39 & 54.2 & 19 & 42.3 & 19 & 41.3 & 44 & 49.4 & 21 & 43.8 \\
\hline $51-60$ & 17 & 23.6 & 15 & 33.3 & 17 & 37.0 & 22 & 24.7 & 15 & 31.2 \\
\hline$>61$ & 2 & 2.8 & 2 & 4.4 & 1 & 2.2 & 2 & 2.3 & 1 & 2.1 \\
\hline Total & 72 & 100.0 & 45 & 100.0 & 46 & 100.0 & 89 & 100.0 & 48 & 100.0 \\
\hline \multicolumn{11}{|l|}{ Income (RM) } \\
\hline$<5000$ & 2 & 2.8 & 3 & 6.7 & 2 & 4.3 & 5 & 5.6 & 1 & 2.1 \\
\hline $5000-10000$ & 44 & 61.1 & 18 & 40.0 & 19 & 41.3 & 54 & 60.7 & 28 & 58.3 \\
\hline$>10000$ & 26 & 36.1 & 24 & 53.3 & 25 & 54.4 & 30 & 33.7 & 19 & 39.6 \\
\hline Total & 72 & 100.0 & 45 & 100.0 & 46 & 100.0 & 89 & 100.0 & 48 & 100.0 \\
\hline \multicolumn{11}{|l|}{ Sex } \\
\hline Male & 33 & 45.8 & 24 & 53.3 & 29 & 63.0 & 66 & 74.2 & 31 & 64.6 \\
\hline Female & 39 & 54.2 & 21 & 46.7 & 17 & 37.0 & 23 & 25.8 & 17 & 35.4 \\
\hline Total & 72 & 100.0 & 45 & 100.0 & 46 & 100.0 & 89 & 100.0 & 48 & 100.0 \\
\hline \multicolumn{11}{|l|}{ Education } \\
\hline Bachelor & 0 & 0 & 2 & 4.5 & 2 & 4.3 & 3 & 3.4 & 2 & 4.2 \\
\hline Master & 16 & 22.2 & 10 & 22.2 & 4 & 8.7 & 16 & 18.0 & 4 & 8.3 \\
\hline $\mathrm{PhD}$ or equivalent & 56 & 77.8 & 33 & 73.3 & 40 & 87.0 & 70 & 78.6 & 42 & 87.5 \\
\hline Total & 72 & 100.0 & 45 & 100.0 & 46 & 100.0 & 89 & 100.0 & 48 & 100.0 \\
\hline \multicolumn{11}{|l|}{ Employment Status } \\
\hline Full time & 66 & 91.7 & 40 & 88.9 & 44 & 95.7 & 83 & 93.3 & 47 & 97.9 \\
\hline Contract & 6 & 8.3 & 5 & 11.1 & 2 & 4.3 & 6 & 6.7 & 1 & 2.1 \\
\hline Total & 72 & 100.0 & 45 & 100.0 & 46 & 100.0 & 89 & 100.0 & 48 & 100.0 \\
\hline
\end{tabular}


TABLE 6. Analysis of variance (ANOVA) between Malaysian research universities

\begin{tabular}{lcccc}
\hline Variable & Sum of squares & df & F statistics & Significance \\
\hline Work relationships & 0.476 & 4 & 0.277 & 0.893 \\
Work-life balance & 6.955 & 4 & 1.057 & 0.378 \\
Overload & 3.374 & 4 & 0.620 & 0.649 \\
Job security & 4.482 & 4 & 1.053 & 0.380 \\
Control & 1.047 & 4 & 0.321 & 0.864 \\
Resources and & 1.933 & 4 & 0.545 & 0.703 \\
communication & & & & \\
Aspects of the job & 1.893 & 4 & 0.723 & 0.577 \\
Pay and benefits & 0.652 & 4 & 0.091 & 0.985 \\
Health & 0.705 & 4 & 0.538 & 0.708 \\
Individual productivity & 0.431 & 4 & 0.279 & 0.891 \\
\hline
\end{tabular}

$(\beta=-0.195 ; \mathrm{p}=0.020) ;$ and control $(\beta=-0.186$; $\mathrm{p}=0.047)$. Thus, H1a, H1b, H1d, H1e and H1g are all supported. However, overload; resources and communication; and pay and benefits are not significant in their prediction of health. Therefore, H1c, H1f and $\mathrm{H} 1 \mathrm{~h}$ are not supported. Table 7 provides a summary of the results.

A simple regression analysis method is performed to examine the direct effects of health on individual productivity. The $\mathrm{R}^{2}$ for this model is 0.338 , which indicates that $33.8 \%$ of the variances predicting individual productivity are explained by this model. Health is significant and positively related to individual productivity $(\beta=0.581 ; \mathrm{p}=0.000)$. Therefore, $\mathrm{H} 2$ is supported by the results of the present study. Table 8 depicts the results of this analysis.

A multiple regression analysis technique is employed to determine the direct effects of occupational stressors

TABLE 7. Multiple regression analysis of health on occupational stressors

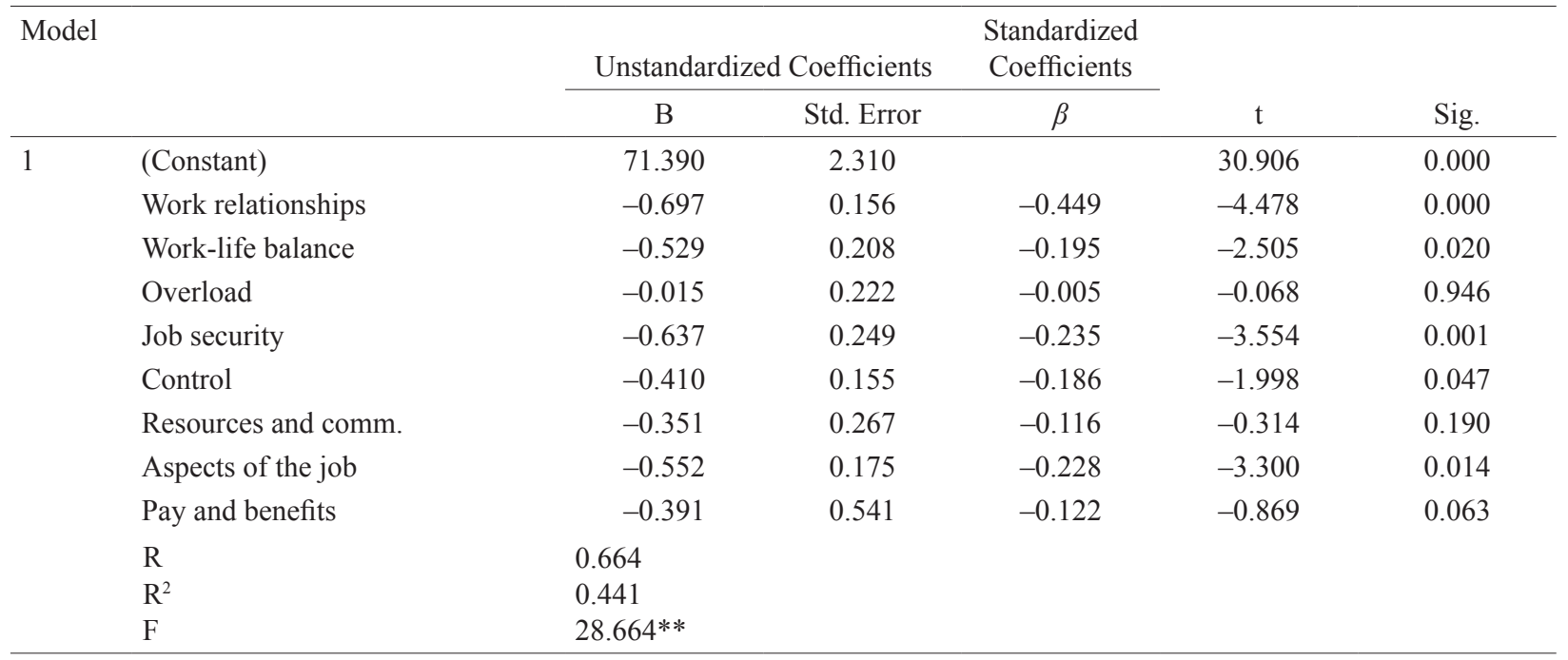

Note: ** and $*$ denote significance at the 0.01 and 0.05 levels, respectively.

TABLE 8. Simple regression analysis of individual productivity on health

\begin{tabular}{|c|c|c|c|c|c|c|}
\hline \multicolumn{2}{|c|}{ Model } & & Unstandardized Coefficients & \multirow{2}{*}{$\begin{array}{c}\text { Standardized } \\
\text { Coefficients }\end{array}$} & \multirow[b]{2}{*}{$\mathrm{t}$} & \multirow[b]{2}{*}{ Sig. } \\
\hline & & B & Std. Error & & & \\
\hline 1 & (Constant) & 20.293 & 7.154 & & 2.836 & 0.005 \\
\hline & Health & 1.807 & 0.147 & 0.581 & 12.331 & 0.000 \\
\hline & $\mathrm{R}$ & 0.581 & & & & \\
\hline & $\mathrm{R}^{2}$ & 0.338 & & & & \\
\hline & $\mathrm{F}$ & $152.062 * *$ & & & & \\
\hline
\end{tabular}

Note: $* *$ and $*$ denote significance at the 0.01 and 0.05 levels, respectively. 
on individual productivity. The $\mathrm{R}^{2}$ of the model is 0.335 , which indicates that $33.5 \%$ of the variances in predicting individual productivity are explained by this model. The dimensions of stressors that are found to be significant and negatively related to individual productivity are work relationships; work-life balance; job security; control; resources and communication; and pay and benefits. The highest contributor is work relationships $(\beta=-0.278$; $\mathrm{p}=0.001)$, followed by job security $(\beta=-0.260$; $\mathrm{p}=0.003)$; pay and benefits $(\beta=-0.230 ; \mathrm{p}=0.018)$; control $(\beta=-0.213 ; \mathrm{p}=0.022)$; work-life balance $(\beta=-0.171 ; \mathrm{p}=0.025)$; and resources and communication $(\beta=-0.146 ; \mathrm{p}=0.029)$. Therefore, H3a, H3b, H3d, H3e, $\mathrm{H} 3 \mathrm{f}$, and $\mathrm{H} 3 \mathrm{~h}$ are all supported. However, overload and aspects of the job are not found to be significant. Hence, $\mathrm{H} 3 \mathrm{c}$ and $\mathrm{H} 3 \mathrm{~g}$ are not supported. The results are depicted in Table 9.

\section{MEDIATION ANALYSIS}

Following the mediational procedures of Baron and Kenny (1986), four analyses must be undertaken. The first analysis involves occupational stressors predicting/ correlating individual productivity. The second analysis observes occupational stressors predicting health. The third analysis involves health predicting individual productivity. Finally, both health and occupational stressors are utilized to predict individual productivity. The first three analyses are conducted through correlation analyses. Therefore, the focus of the present section is the fourth analysis.

The fourth analysis, or final analysis, observes the predictions of both occupational stressors and health together on individual productivity. The analysis is performed in two steps using hierarchical regression analysis. In step 1, all occupational stressors variables are entered together. As in the previous results, Model
1 yields $33.5 \%$ of the variances in predicting individual productivity $\left(\mathrm{R}^{2}=0.335\right)$. In step 2 , health is entered. The $\mathrm{R}^{2}$ for model 2 is 0.428 and indicates $42.8 \%$ in predicting variances in individual productivity. $\Delta \mathrm{R}^{2}$ of 0.092 shows that the inclusion of health increases the predictive power of the model by $9.2 \%(\Delta \mathrm{F}$ statistics $=46.771$; $\mathrm{p}<0.01$ ). Individual stressors that are reduced, but maintain significance, are work relationships $(\beta=-0.186$; $\mathrm{p}<0.05)$; job security $(\beta=-0.165 ; \mathrm{p}<0.05)$; control $(\beta=-0.162 ; \mathrm{p}<0.05)$; and work-life balance $(\beta=-0.142$; $\mathrm{p}<0.05)$. Health remained significant and positive in its relationship to individual productivity in Model 2 ( $\beta=0.406 ; \mathrm{p}<0.01)$. Hence, H4a, H4b, H4d and H4e are all partially supported. Other stressors are not significant in their relationships to either individual productivity or health prior to the fourth analysis, including overload; resources and communication; aspects of the job; and pay and benefits. Therefore, H4c, H4f, H4g and H4h are not supported. The results of the final steps of the mediation analysis of health as a mediator between stressorsindividual productivity relationships are summarized in Table 10.

Next, the sizes of the products of the indirect effects for health as a mediator are analyzed. The largest amount of indirect effects is found in the work relationshipshealth-individual productivity relationship $(-0.261)$, which is followed by the job security-health-individual productivity relationship ( -0.137$)$; the work-life balancehealth-individual productivity relationship $(-0.113)$; and the control-health-individual productivity relationship $(-0.108)$. The results are depicted in Table 11 .

Finally, the Sobel test (Sobel 1982) is conducted to determine the significance of the indirect effects for mediator health. The interactive calculator is employed (Preacher \& Leonardelli 2010). The highest significance among indirect effects is observed from the work relationships-health-individual productivity relationship

TABLE 9. Multiple regression analysis of individual productivity on occupational stressors

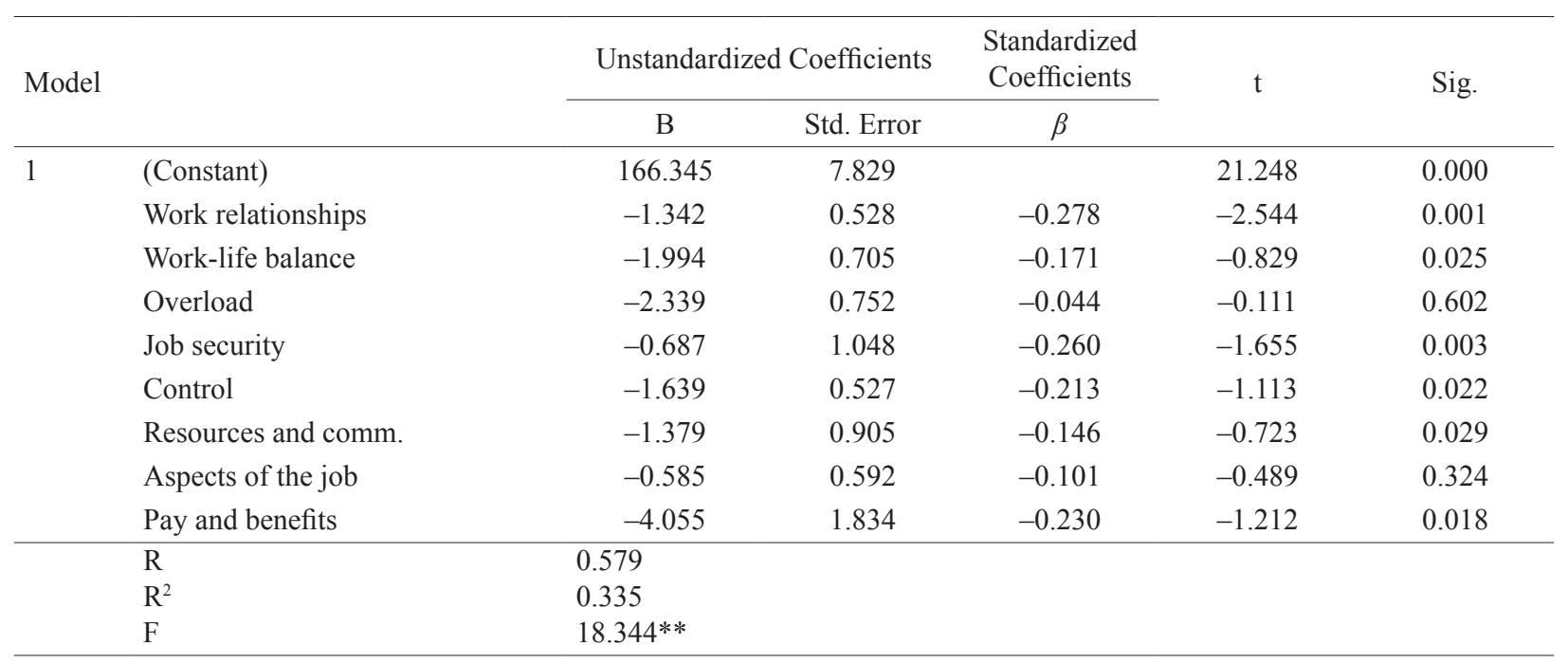

Note: $* *$ and $*$ denote significance at the 0.01 and 0.05 levels, respectively. 
TABLE 10. Hierarchical regression analysis of individual productivity on occupational stressors and health

\begin{tabular}{|c|c|c|c|c|c|c|}
\hline \multirow{2}{*}{ Variable } & \multicolumn{3}{|c|}{ Step 1} & \multicolumn{3}{|c|}{ Step 2} \\
\hline & $\mathrm{B}$ & SE & $\beta$ & $\mathrm{B}$ & SE & $\beta$ \\
\hline Work relationships & -1.342 & 0.528 & $-0.278^{*}$ & -0.462 & 0.507 & $-0.186^{*}$ \\
\hline Work-life balance & -1.994 & 0.705 & $-0.171^{*}$ & -1.074 & 0.669 & $-0.142 *$ \\
\hline Overload & -2.339 & 0.752 & -0.044 & -1.320 & 0.699 & -0.022 \\
\hline Job security & -0.687 & 1.048 & $-0.260^{*}$ & -1.997 & 0.993 & $-0.165^{*}$ \\
\hline Control & -1.639 & 0.527 & $-0.213^{*}$ & -1.247 & 0.493 & $-0.162 *$ \\
\hline Resources and comm. & -1.379 & 0.905 & $-0.146^{*}$ & -0.936 & 0.844 & -0.099 \\
\hline Aspects of the job & -0.585 & 0.592 & -0.101 & -0.519 & 0.550 & -0.090 \\
\hline Pay and benefits & -4.055 & 1.834 & $-0.230^{*}$ & -2.778 & 1.715 & -0.108 \\
\hline Health & & & & 1.263 & 0.185 & $0.406^{* *}$ \\
\hline $\mathrm{R}^{2}$ & & 0.335 & & & 0.428 & \\
\hline$\Delta \mathrm{R}^{2}$ & & & & & 0.092 & \\
\hline$\Delta \mathrm{F}$ statistics & & $18.344^{* *}$ & & & $46.771 * *$ & \\
\hline
\end{tabular}

Note: $* *$ and $*$ denote significance at the 0.01 and 0.05 levels, respectively.

TABLE 11. The size of indirect effects with health as the mediator

\begin{tabular}{lccc}
\hline Mediation effects & Path a & Path $\mathrm{b}$ & Size: $\mathrm{a} \times \mathrm{b}$ \\
\hline $\mathrm{WR} \rightarrow$ HEA $\rightarrow$ IP & -0.449 & 0.581 & -0.261 \\
$\mathrm{WLB} \rightarrow$ HEA $\rightarrow$ IP & -0.195 & 0.581 & -0.113 \\
$\mathrm{JS} \rightarrow$ HEA $\rightarrow$ IP & -0.235 & 0.581 & -0.137 \\
$\mathrm{CTL} \rightarrow$ HEA $\rightarrow$ IP & -0.186 & 0.581 & -0.108 \\
\hline
\end{tabular}

Note: $\mathrm{WR}=$ work relationship; $\mathrm{WLB}=$ work-life balance; JS $=$ job security; $\mathrm{CTL}=$ control; HEA $=$ health; $\mathrm{IP}=$ individual productivity.

(test statistics $=-3.7385 ; \mathrm{p}<0.01$ ), followed by the control-health-individual productivity relationship (test statistics $=-2.4665 ; \mathrm{p}<0.05$ ); the job security-healthindividual productivity relationship (test statistics $=$ $-2.3956 ; \mathrm{p}<0.05)$; and the work-life balance-healthindividual productivity relationship (test statistics $=$ $-2.3833 ; \mathrm{p}<0.05)$. Table 12 summarizes the results.

\section{DISCUSSION AND CONCLUSIONS}

The presents study examines the mediating effects of health on the relationships between occupational stressors and individual productivity among academic administrators in MRUs utilizing mediation analysis and the Sobel test. The findings indicate that health partially mediates the effects between certain occupational stressors, such as work relationships, work-life balance, job security, and control, on individual productivity. A study by Darr and Johns (2008) also demonstrates similar findings. Academic administrators at MRUs not only developed poor health because of stress, but they also developed poor individual productivity. The most significant indirect effects mediated by health are found in the work relationships-health-individual productivity relationship. High levels of stress due to poor work relationships leads to low levels of health and low levels of individual productivity. Academic administrators may feel angry, or even anxious, because of poor relationships with their bosses or colleagues. Publication productivity may in jeopardy (e.g., decrease in the number of articles published in journals) because of the lack of support of team members. High levels of stress are also caused by poor work-life balance; job security; and control, which can lower a person's health levels and lead to a deterioration of individual productivity levels. Academic administrators at MRUs who work long hours, for example, have difficulty concentrating on their jobs, which jeopardizes their teaching productivity or the number of courses taught. Poor job control, on the other hand, may cause anxiety attacks or mood swings which can prevent them from advising students or result in a decrease in the number of student mentored/advised formally. Health however, did not mediate the relationships between overload, resource and communications, aspects of the job and pay and benefits; and individual productivity.

The implications for MRUs include not only working to eliminate the stressors identified in the present study (i.e., work relationships, work-life balance, job security and control), but also improving and maintaining the staffs' levels of health and individual productivity, particularly that of academic administrators. Overall, the present study finds that stress is affecting academic administrators at MRUs. Occupational stressors are found to be the causes of these stresses and include work relationships; work-life balance; overload; job 
TABLE 12. The Sobel test of indirect effects significant with health as the mediator

\begin{tabular}{|c|c|c|c|c|}
\hline Indirect effects & Input & Test statistics & Standard error & P-value \\
\hline \multicolumn{5}{|l|}{ WR $\rightarrow$ HEA $\rightarrow$ IP } \\
\hline Unstandardized coefficient a & -0.697 & -3.7385 & 0.2355 & 0.0002 \\
\hline Unstandardized coefficient $b$ & 1.263 & & & \\
\hline Standard error a & 0.156 & & & \\
\hline Standard error $b$ & 0.185 & & & \\
\hline \multicolumn{5}{|l|}{ WLB $\rightarrow$ HEA $\rightarrow$ IP } \\
\hline Unstandardized coefficient a & -0.529 & -2.3833 & 0.2803 & 0.0172 \\
\hline Unstandardized coefficient $b$ & 1.263 & & & \\
\hline Standard error a & 0.208 & & & \\
\hline Standard error $b$ & 0.185 & & & \\
\hline \multicolumn{5}{|l|}{$\mathrm{JS} \rightarrow \mathrm{HEA} \rightarrow \mathrm{IP}$} \\
\hline Unstandardized coefficient a & -0.637 & -2.3956 & 0.3358 & 0.0166 \\
\hline Unstandardized coefficient $b$ & 1.263 & & & \\
\hline Standard error a & 0.249 & & & \\
\hline Standard error $b$ & 0.185 & & & \\
\hline \multicolumn{5}{|l|}{$\mathrm{CTL} \rightarrow \mathrm{HEA} \rightarrow \mathrm{IP}$} \\
\hline Unstandardized coefficient a & -0.410 & -2.4665 & 0.2099 & 0.0136 \\
\hline Unstandardized coefficient $b$ & 1.263 & & & \\
\hline Standard error a & 0.155 & & & \\
\hline Standard error $b$ & 0.185 & & & \\
\hline
\end{tabular}

security; control; resources and communications; aspects of the job; and pay and benefits. Occupational stressors may directly or indirectly affect health and individual productivity levels. Therefore, organizations, particularly MRUs, should take action in order to alleviate stress at their workplaces and improve the health and individual productivity of academic administrators.

The present study also suggests further research in this area in the form of longitudinal research design, which can provide further evidence to the cause and effect relationships between stressors-strain-productivity relationships. New productivity variables can provide a new research direction in this field of study, such as medical cost, absenteeism, as well as presenteeism. Clinical research on stress is also lacking. Therefore, clinical research on stress is also recommended in the future. More importantly, the new productivity measures developed in the present study can be tested further in future studies.

\section{REFERENCES}

Abramis, D. J. 1994. Work role ambiguity, job satisfaction, and job performance: meta-analyses and review. Psychological Reports, 75(3): 1411-1433.

Aronsson, G., Gustafsson, K. \& Dallner, M. 2000. Sick but yet at work: An empirical study of sickness presenteeism. Journal of Epidemiol Community Health 54: 502-509.

Baron, R. M. \& Kenny, D. A. 1986. The moderator-mediator variable distinction in social psychological research: Conceptual, strategic, and statistical considerations. Journal of Personality and Social Psychology 51(6): 1173-1182.
Beehr, T. A. 1995. Psychological stress in the workplace. New York: Routledge.

Beehr, T. A. 2002. An organizational psychology meta-model of occupational stress. In Theories of Organizational Stress, edited by Cooper, C.L., 6-27. New York: Oxford.

Beehr, T. A. \& Franz, T. M. 1987. The current debate about the meaning of job stress. In Job Stress: From Theory to Suggestion, edited by Ivancevich, J. M. and Ganster, D. C., 5-18. New York: Haworth Press.

Beehr, T. A. \& Newman, J. E. 1978. Job stress, employee health and organizational effectiveness: A facet analysis, model, and literature review. Personnel Psychology 31: 665-699.

Boles, M., Pelletier, B. \& Lynch, W. 2004. The relationship between health risks and work productivity. Journal of Occupational and Environmental Medicine 46(7): 737 745.

Blackburn, R. T. \& Lawrence, J. H. 1995. Faculty at Work: Motivation, Expectation, Satisfaction. Baltimore, MD, US: John Hopkins University Press.

Bridger, R. S., Kilminster, S. \& Slaven, G. 2007. Occupational stress and strain in the naval service: 1999 and 2004. Occupational Medicine 57: 92-97.

Brouwer, W. B. F., Koopmanscap, M. A. \& Rutten, F. F. H. 1999. Productivity losses without absence. Health Policy 48: 13-27.

Cartwright, S. \& Cooper, C. L. 2002. ASSET: The Management Guide. Manchester: Robertson Cooper Ltd.

Cavana, R. Y., Dlahaye, B. L. \& Sekaran, U. 2001. Applied Business Research: Qualitative And Quantitative Methods. New York: Wiley.

Creswell, J. W. 1985. Faculty research performance: Lessons from the sciences and the social sciences. ASHE-Eric Higher Education Report No. 4. Washington DC: ASHE. 
Crosta, P. M. \& Packman, G. I. 2005. Faculty productivity in supervising doctoral students' dissertations at Cornell University. Economics of Education Review 24: 55-65.

Darr, W. \& Johns, G. 2008. Work strain, health, and absenteeism from work: A meta analysis. Journal of Psychological Health Psychology 13(4): 293-318.

Donald. I., Taylor, P., Johnson, S., Cooper, C., Cartwright, S. \& Robertson, S. 2005. Work environments, stress and productivity: An examination using ASSET. International Journal of Stress Management 12(4): 409-423.

Faragher, E. B., Cooper, C. L. \& Cartwright, S. 2004. A shortened stress evaluation tool (ASSET). Stress \& Health 20: 189-201.

George, D. \& Mallery, P. 2001. SPSS for Windows Step by Step: A Simple Guide and Reference 10.0 update. $3^{\text {rd }}$ edition. Toronto, Canada: Allyn and Bacon.

Gmelch, W. H., Wolverton, M., Wolverton, M. L. \& Sarros, J. C. 1999. The academic dean: An imperil species searching for balance. Research in Higher Education 40(6): 717-740.

Greenberg, P., Stiglin, L., Finkelstein, S. \& Berndt, E. 1993. The economic burden of depression in 1990. Journal of Clinical Psychiatry 54(11): 405-418.

Hagedorn, L. S. 1996. Wage equity and female faculty satisfaction: The role of wage differentials in a job satisfaction causal model. Research in Higher Education 37(5): 569-598.

Hassan, A., Tymms, P. \& Ismail, H. 2008. Academic productivity as perceived by Malaysian academics. Journal of Higher Education Policy and Management 30(3): 283-296.

Heuval, S. G. V. D., Geuskens, G. A., Hooftman, W. E. Koppes, L. L. J. \& Bossche, S. N. J. V. D. 2010. Productivity loss at work: Health-related and work-related factors. Journal of Occupational Rehabilitation 20: 331-339.

Jackson, L. \& Rothmann, S. 2006. Occupational stress, organizational commitment, and ill-health of educators in the North West Province. South African Journal of Education 26(1): 75-95.

Jacobs, P. A., Tytherleigh, M. Y., Webb, C. \& Cooper, C. L. 2007. Predictors of work performance among higher education employees: An examination using ASSET model of stress. International Journal of Stress Management 14(2): 199-210.

Jamal, M. 1984. Job stress and job performance controversy: An empirical assessment. Organizational Behavior and Human Performance 33: 1-21.

James, R. \& Baldwin, G. 2006. Eleven practices of effective postgraduate supervisors. Centre for the Study of Higher Education \& The School of Graduate Studies, Australia. http://www.sche.unimelb.edu.au./pdfs/11 practices.pdf [January 5, 2010].

Johnson, S. \& Cooper, C. 2003. The construct validity of the ASSET stress measure. Stress and Health 19: 191-185.

Judd, C. M. \& Kenny, D. A. 1981. Process analysis: Estimating mediation in treatment evaluations. Evaluation Review 5: 602-619.

Kahn, R. L. \& Byosiere, P. 1992. Stress in organizations. In Handbook of Industrial and Organizational Psychology, edited by Dunnette, M. D. 571-648. Chicago: Rand McNally.

Kelloway, E. K., Teed, M. \& Kelley, E. 2008. The psychosocial environment: Towards an agenda for research. International Journal of Workplace Health Management 1(1): 50-64.
Kennedy, D. 1997. Academic Duty. Cambridge, MA: Harvard University Press.

Kerlinger, F. N. \& Lee, H. B. 2000. Foundations of Behavioural Research. $4^{\text {th }}$ edition. Australia: Thomson.

Ketteridge, S. \& Shiach, M. 2009. Supervising research students. In A handbook for Teaching and Learning in Higher Education: Enhancing Academic Practice, edited by Fry, H., 166-185. New York: Routledge.

Krejcie, R. V. \& Morgan, D. W. 1970. Determining sample size for research activities. Educational \& Psychological Measurement 30: 607-610.

Lang, J., Thomas, J. L., Bliese, P. D. \& Adler A. B. 2007. Job demands and job performance: The mediating effects of psychological and physical strain and the moderating effect of role clarity. Journal of Occupational Health Psychology 12(2): 116-124.

Loeppke, R., Taitel, M, Richling, D., Parry, T., Kessler, R.C., Hymel, P. 2007. Health and productivity as a business strategy. Journal of Occupational and Environmental Medicine 49: 712-721.

Mamiseishvili, K. \& Rosser, V. J. 2010. International and citizen faculty in the United States: An examination of their productivity at research universities. Research in Higher Education 51: 88-107.

Manning, M. R., Jackson, C. N. \& Fusilier, M. R. 1996. Occupational stress, social support, and health care cost. Academy of Management Journal 39(3): 738-750.

Massy, W. \& Wilgers, A. 1995. Improving productivity: What faculty thinks about it and its effect on quality. Change 27(4): 10-21.

Michailidis, M. \& Asimenos, A. 2002. Occupational stress as it relates to higher education, individuals and organizations. Work 19: 137-147.

Middaugh, M. F. 2001. Understanding Faculty Productivity: Standards and Benchmarks for Colleges and Universities. San Francisco: Wiley.

Middaugh, M. F. 2008. The role of institutional research in understanding and describing faculty work: New Directions for Higher Education 141: 41-56.

Miller, J. L. 2003. Faculty scholarship, service, teaching, salary satisfaction, and job satisfaction, in accredited and non-accredited counselor education graduate programs. $\mathrm{PhD}$ thesis. Counselor Education Program. University of New Orleans.

Mostert, F. F., Rothmann, S., Mostert, K. \& Nell, K. 2008. Outcomes of occupational stress in a higher education institution. Southern African Business Review 12(3): 102-127.

Newsom, R. J. 2010. Testing mediation with regression analysis. http:// www. upa. pdx. edu/ IOA/ newsom/ semclass/ ho indirect.pdf [April 4, 2011].

Phillips, S., Sen, D. \& McNamee, R. 2008. Risk factors for work-related stress and health in head teachers. Occupational Medicine 58: 584-586.

Preacher, K. J. \& Leonardelli, G. J. 2010. Calculation for the Sobel test: An interactive calculation tool for mediation tests. http://www.quantpsy.org/sobel/sobel.htm. Retrieved on: September 7, 2012.

Print, M. \& Hattie, J. 1997. Measuring quality in universities: An approach to weighting research productivity. Higher Education 33: 453-469. 
Provost, M. W. 2005. A study of four public higher education institutions in Florida: The relationships between faculty and administrator goal congruence, faculty productivity, and job satisfaction. Doctor of Education thesis. The College of Education, Florida University.

Rosser, V. J. \& Tabata, L. N. 2010. An examination of faculty work: Conceptual and theoretical frameworks in the literature. In Higher Education: Handbook of Theory and Research, edited by Smart, J. C., 449-475. New York: Springer.

Schultz, A. B. \& Edington, D. W. 2007. Employee health and presenteeism: A systematic review. Journal of Occupational Rehabilitation 17: 547-579.

Selye, H. 1973. The evolution of the stress concept. Scientist 61(November): 692-699.

Selye, H. 1976. The stress of life. In Workstress, edited by Sulsky, L \& Smith, C, 22-24. USA: Thomson.

Sobel, M. E. 1982. Asymptotic confidence intervals for indirect effects in structural equation models. In Sociological Methodology, edited by Leinhardt, S., 290-312. Washington D. C.: American Sociological Association.

Spector, P. E., Dwyer, D. J. \& Jex, S. M. 1988. Relation of job stressors to affective, health, and performance: A comparison of multiple data sources. Journal of Applied Psychology 73(1): 11-19.

Tarafdar, M., Tu, Q., Ragu-Nathan, B. S., \& Ragu-Nathan, T. S. 2007. The impact of technostress on role stress and productivity. Journal of Management Information System 24(1): 301-328.

Trade Union Council. 2000. Focus on health and safety: stress at work tops safety poll. http//www.tuc.org.uk/h_and_s/ tuc-2390-f0.cf. Retrieved on: December 20, 2009.

Tytherleigh, M. Y., Webb, C., Cooper, C. L. \& Ricketts, C. 2005. Occupational stress in UK higher education institutions: A comparative study of all staff categories. Higher Education Research \& Development 24(1): 41-61.

UKM website. 2010. http://www.ukm.my/v3/. Retrieved on: January 15, 2010.

UM.website. 2010. http://www.um.edu.my/. Retrieved on: January 15, 2010.

University of Nevada. 2007. Academic faculty evaluation "toolkit". http://www.unr.edu/hr/employeeperformance/ toolkit1.html [July 5, 2010].

UPM website. 2010. http://www.upm.edu.my/. Retrieved on: January 20, 2010.

USM website. 2010. http://www.usm.my/. Retrieved on: February 14, 2010.
UTM website. 2010. http://www.utm.my/. Retrieved on: February 20, 2010.

Viljoen, J. P. \& Rothmann, S. 2009. Occupational stress, ill health and organizational commitment of employees at a university of technology. SA Journal of Industrial Psychology/SA Tydskrif vir Bedryfsielkunde 35(1): 1-11.

Winefield, A. H., Gillespie, N., Stough, C., Dua, J. K. \& Hapuarachchi, J. 2003. Occupational Stress in Australian Universities: A National Survey. Melbourne: National Tertiary Education Union.

Young, P. T. 1936. Motivation of Behavior: The Fundamental of Determinants of Human and Animal Activity. New York: Wiley.

Zafir Mohd Makhbul. 2012a. Correlation analysis between ergonomics and stress at the workplace. International Business Management 6(6): 648-651.

Zafir Mohd Makhbul. 2012b. Workplace Environment towards Health and Performance. International Business Management 6(6): 640-647.

Zafir Mohamed Makhbul \& Fazilah Mohamad Hasun. 2007. Ergonomik dan stres di Malaysia: Implikasi terhadap teori, metodologi dan pengurusan. Jurnal Pengurusan 26: 99-130.

Zafir Mohd Makhbul, Syed Shah Alam, Shaza Marina Azmi \& Norliza Abu Talib. 2011. Ergonomics and work stress issues in banking sector. Australian Journal of Basic and Applied Sciences 5: 1301-1309.

Zafir Mohamed Makhbul, Zizah Che Senik \& Norliza Abdullah. 2013. Ergonomics and Stress at the Workplace: Engineering Contributions to Social Sciences. Jurnal Pengurusan 37: 125-131.

\section{Zafir Mohd Makhbul}

Fakulti Ekonomi Dan Pengurusan

Universiti Kebangsaan Malaysia

43600 UKM Bangi, Selangor

MALAYSIA

zafir@ukm.edu.my

Sheikh Muhamad Hizam Hj. Sheikh Khairuddin

Faculty of Business and Management

Kuala Lumpur Metropolitan University College

Wisma Sachdev, 16-2

Jalan Raja Laut

50350 Kuala Lumpur

MALAYSIA 
